\title{
Agricultural Credit Sources and Determinants of Credit Acquisition by Farmers in Idemili Local Government Area of Anambra State
}

\author{
John Chinasa Ijioma and Charles Kelechi Osondu \\ Department of Agricultural Economics and Extension, Abia State University Uturu, Umuahia Campus PMB 7010, Umuahia, Nigeria
}

\begin{abstract}
The study is focused on agricultural credit sources and determinants of credit acquisition by farmers in Idemili local government area of Anambra State, Nigeria with specific objectives to: describe socio-economic characteristics of rural farmers; identify sources of agricultural credit available to rural farmers; determine socio-economic factors that influence agricultural credit acquisition of farmers; ascertain reasons for any credit misappropriation and identify problems that constrain farmers from agricultural credit acquisition. Ninety farmers were randomly selected by multi stage random sampling technique. Semi-structured questionnaire was used to elicit data for the study. Descriptive statistics and multiple regression model were used in achieving the objectives. Results indicated that $74.44 \%$ of respondents were males with a mean age of 45 years. Majority $(76.67 \%)$ were married with large house hold sizes. Majority (93.33\%) received different level of education, with sources of credit from friends/relatives (30.00\%), cooperative societies (43.33\%), money lenders (14.44\%), and cumulatively from formal sources ((12.22\%). The result of the multiple regression analysis revealed age, household size, membership of cooperative societies, marital status, education level, farm size and amount of loan repaid at varied signs and levels as significant predictors of amount of agricultural credit acquired by farmers. The most common reason given among the respondents (55.89\%) of those who misappropriated acquired agricultural credit, was meeting nonfood needs of the household. The farmers encountered problems of high interest rate (78.89\%), lack of collateral $(75.56 \%)$, long distance from source of credit $(50.00 \%)$, poor harvest (37.78\%), moratorium (33.33\%) and delay in loan approval/disbursement $(44.44 \%)$ as constraints to acquire credit. The study recommends that the state government should pass policies aimed at providing free educative seminars to all illiterate farmers to teach them possible ways and methods of acquiring credit. To ensure mass attendance to such seminars, little incentives should be given to farmer participants.
\end{abstract}

Key words: Credit, acquisition, misappropriation, formal credit, informal credit.

\section{Introduction}

Agriculture, which is the cultivation of crops and rearing of livestock for the satisfaction of human needs, is the most important sector towards the development of any nation [1]. Agriculture provides the greatest avenue for employment, income and food for Nigerian populace (general public). The agricultural sector has been an important component of the Nigerian economy with peasant farmers producing over $90 \%$ of available food in the country and $70 \%$ of the labour force relying on this sectors [2].

\footnotetext{
Corresponding author: Charles Kelechi Osondu, Ph.D., research field: agricultural economics. E-mail: osonducharles87@gmail.com.
}

Agricultural sector incidentally lies in the hands of small scale farmers, whose expansion in terms of provision of scale of production is low due to low inputs and low income. The decline in the Nigerian economy, particularly in the area of agricultural productivity, has often been blamed on lack of credit facilities, which prevented many farmers from adopting improved practices, since some of them lack the collateral for secure loan or credit from financial institutions [3]. According to Alfred [4], acquisition and utilization of credit for agricultural purposes promote productivity and consequently improve food security status of a community. Good access to credit would enable farmers venture into new areas as well 
as acquire improved technology for enhanced performances. Nnanna [5] and Olaitan [6] identified several credit policies and guidelines, which ensure availability of credit through rural banking scheme. These include sectional allocation of credit, concessionary interest rate, and specified percentage of total deposit mobilized in the rural areas.

Credit is an important support service for increased agricultural productivity. Nwaru et al. [7] observed that credit facilitates adoption of innovations, leading to increased farm productivity and income, encourages capital formation and improves marketing efficiency. In addition, it enables farmers to purchase inputs, hire labour and procure equipment and improved seed varieties for increased agricultural production. The need for credit is more acute in the rural areas, because access to financial resources is lowered by low productivity and wide spread poverty of the rural farm sector. This low productivity is purely due to the fact that they produce for subsistence consumption and a little marketable surplus. Crude and rudimentary implements are used to produce food for ever increasing population. Price fluctuation of both inputs and output in agriculture causes low level of income to farmers. These are the major reasons why rural farmers are poor. There are two major sources of agricultural credit, that is, formal and informal sources. In the formal credit, institutions provide intermediation between depositors and lenders, and charge farmers for relatively lower rates of loans interest that usually are government subsidized. In informal credit, markets money is lent by private individuals. The informal sources of credit to smallholder farmers as identified in the study area were family or friends, money lenders, produce buyers and farmers' cooperatives, while the formal sources of credit were Nigerian agricultural cooperative and rural development bank, microfinance banks and commercial bank. One cannot be in doubt that Nigeria government have embarked on good credit policies to ensure availability and accessibility of credit to enhance rural farming, such as rural banking programme, micro finance banks, agricultural credit guarantee scheme and Nigeria agricultural co-operative and rural development bank.

Agricultural credit is any of the several credit vehicle used to finance agricultural transaction, including loans, notes, bills of exchange and bankers acceptances. These types of financing are adapted to the specific financial needs of farmers, which are determined by planting, harvesting and marketing cycles. Short term credit and intermediate term credit are used for obtaining farm inputs, such as fertilizer, improved seeds, breeding livestock and farm machinery, while long term credit is used for real-estate financing [8]. Credit inadequacy has been a problem militating against the development of the rural farmers in the world at large and Nigeria in particular. This inadequacy is caused by a number of factors, which include the part of farmers lack of knowledge of the sources of credit. The credit inadequacy has been a major problem militating against the effectiveness and development of rural farmers in Idemili North local government area of Anambra State, and thus it is need for credit source to help break this vicious cycle of poverty that exists among them and thereby improve their socio-economic well-being.

However, most banks closed some of their rural branches which compounded the problem of rural farmers' inadequate credit access. The main reason for this were the inability of the farmers to cope with the prevailing interest rate and other credit requirements, which made the banks operate at a loss in such areas [9]. Banks are unwilling to lend farmers credit because of the inherent risk associated with the agricultural sector and inability of farmers to provide necessary collateral. Moreover, banks are uncomfortable with the high cost of credit administration to farmers. Farmers on their own are unwilling to procure credit from banks because of lengthy and cumbersome loan procurement procedure, 
high cost of bank loan, untimely disbursement of loan by banks and long distance from source of loan [9-11]. This study becomes pertinent in view of the foregoing issues and sought to: (1) describe the socio-economic characteristics of rural farmers in Idemili North local government area; (2) identify sources of agricultural credit available to rural farmers in Idemili North local government area; (3) determine socio-economic factors that influence agricultural credit acquisition of farmers in the study area; (4) ascertain reasons for any credit misappropriation and identify problems that constrain farmers from agricultural credit acquisition.

\section{Materials and Methods}

The study was carried out in Idemili North local government area of Anambra State. The local government area is located in the South Eastern Region of Nigeria within longitudes $6^{\circ} 36^{\prime} \mathrm{E}$ and $7^{\circ} 21^{\prime} \mathrm{E}$ of the Greenwich Meridian and latitudes $5^{\circ} 38^{\prime} \mathrm{N}$ and $6^{\circ} 47^{\prime} \mathrm{N}$ of the Equator. According to Ref. [12], Idemili local government area has a population of 430,783 . The study area is bounded on the north by Dunukofia, Njikoka and Anaocha local government areas, on the south by Onitsha North and South local government areas, on the east by Idemili South local government area and on the west by Oyi local government area. The climate can generally be described as tropical with two clear identifiable seasons - the wet and dry season. Farming is the predominant occupation of the people. They are involved in major crops include yam, cassava, rice, maize, cocoyam, cowpea and tomatoes. They are also involved in poultry, sheep, goats and pig production.

A multi stage random sampling technique was used for this study. In the first stage, three autonomous communities, namely, Obosi, Ogidi and Nkpor, were randomly selected. In the second stage, three villages were randomly selected from each of the three communities to give a total number of nine villages. Lastly, at the village level, 10 farmers were randomly selected giving a total of 90 respondents for the study.
Primary data was used for the study. The data were obtained through the use of semi-structured questionnaire, which was administered by the researchers. Oral interview and observation were used to augment sources.

Descriptive statistics, such as frequency distribution tables and percentagesm, were used in achieving objectives (1), (2) and (4). While ordinary least square (OLS) multiple regression model was used in achieving objective (3). The four functional forms of the OLS multiple regression model, namely, linear, double logarithmic, exponential and semi-logarithmic functions, were fitted with the data. The lead-equation was selected based on statistical and econometric criteria, which include the magnitude of $R^{2}$, the significant level of the F-ratio, the number of significant variables and the conformity of the variables to a priori expectations.

The four functional forms of OLS model are explicitly stated as:

Linear function:

$Y=\mathrm{a}+b_{1} x_{1}+b_{2} x_{2}+b_{3} x_{3}+b_{4} x_{4}+b_{5} x_{5}+b_{6} x_{6}+b_{7} x_{7}$

$$
+b_{8} x_{8}+b_{9} x_{9}+b_{10} x_{10}+e_{i}
$$

Semi-log function:

$Y=\mathrm{a}+b_{1} \ln x_{1}+b_{2} \ln x_{2}+b_{3} \ln x+b_{4} \ln x_{4}+b_{5} \ln x_{5}+$

$$
b_{6} \ln x_{6}+b_{7} \ln x_{7}+b_{8} \ln x_{8}+b_{9} \ln x_{9}+b_{10} x_{10}+e_{i}
$$

Double-log function:

$\ln Y=\mathrm{a}+b_{1} \ln x_{1}+b_{2} \ln x_{2}+b_{3} \ln x_{3}+b_{4} \ln x_{4}+b_{5} \ln x_{5}+$

$$
b_{6} \ln x_{6}+b_{7} \ln x_{7}+b_{8} \ln x_{8}+b_{9} \ln x_{9}+b_{10} x_{10}+e_{i}(3)
$$

Exponential function:

$$
\begin{aligned}
\ln Y= & \mathrm{a}+b_{1} x_{1}+b_{2} x_{2}+b_{3} \ln x_{3}+b_{4} x_{4}+b_{5} x_{5}+b_{6} x_{6}+ \\
& b_{7} \ln x_{7}+b_{8} x_{8}+b_{9} x_{9}+b_{10} x_{10}+e_{i}
\end{aligned}
$$

where,

$Y=$ volume of credit obtained ( $)$;

$x_{1}=$ age of farmers (years);

$x_{2}=$ household size(number);

$x_{3}=$ education level (number of schooling years);

$x_{4}=$ farming experience (years);

$x_{5}=$ farm size (hectares);

$x_{6}=$ loan repayment (Naira);

$x_{7}=\operatorname{gender}(1=$ male, $0=$ female $)$; 
$x_{8}=$ co-operative society $(1=$ member, $0=$ non-member);

$x_{9}=$ marital status $(1=$ married, $0=$ single $)$;

$x_{10}=$ farming status (full time $=1$ and part time $=0$ );

$\mathrm{a}=$ constant intercept;

$b_{1} \ldots b_{10}=$ the coefficient corresponding to $x_{1} \ldots x_{10}$;

$e=$ stochastic error.

\section{Results and Discussion}

\subsection{Socio-economic Characteristics of Respondents}

The socio-economic characteristics of respondents are presented in Table 1. Table 1 shows that majority (74.44\%) of the respondents that acquired external agricultural credit were males, while $25.56 \%$ of them were females. Although, this study is not gender based, the result underlies the fact that males in the study area had greater access to production resources. The male dominance of this rural source of livelihood implies the laborious nature of farming operations from tillage to harvest, which their female counterparts cannot easily undertake. This is because farming operations require a lot of energy and are labour intensive especially in the rural areas, where crude farm implements are usually used. This agrees with the finding of Asogwa et al. [3] and Olaleye [13] that small-scale farming is being carried out mostly by males, while females involve in light farm operations such as processing, harvesting and marketing. The table also shows that a fair percentage (40.00\%) and (31.11\%) of the respondents were within the age range of 41 years old to 50 years old and of 51 years old to 60 years old, respectively, while $22.22 \%$ and $6.67 \%$ of them fell within the age range of 31 years old to 40 years old and 61 years old to 70 years old, respectively. The mean age of respondents is 45 years old. The implication of this result is that farming in the area was dominated by young people, who are energetic enough to withstand the stress involved in farm operations. The table shows that $76.66 \%$ of the respondents were married and therefore would have greater family responsibility, while $23.34 \%$ of the respondents were single.

The table also shows that a good percentage (56.67\%) of the respondents' household size were between the range of 6-10 persons, while $43.33 \%$ of the respondents

Table 1 Socio-economic characteristics of respondents.

\begin{tabular}{|c|c|c|}
\hline Variables & Frequency & Percentage (\%) \\
\hline \multicolumn{3}{|l|}{ Gender } \\
\hline Male & 67 & 74.44 \\
\hline Female & 23 & 25.56 \\
\hline \multicolumn{3}{|l|}{ Age } \\
\hline $31-40$ & 20 & 22.22 \\
\hline $41-50$ & 36 & 40.00 \\
\hline $51-60$ & 28 & 31.11 \\
\hline $61-70$ & 6 & 6.67 \\
\hline \multicolumn{3}{|l|}{ Mean age $=44.5$} \\
\hline \multicolumn{3}{|l|}{ Marital status } \\
\hline Married & 69 & 76.67 \\
\hline Single & 21 & 23.34 \\
\hline \multicolumn{3}{|l|}{ Household size } \\
\hline $1-5$ & 39 & 43.33 \\
\hline $5-10$ & 51 & 56.67 \\
\hline \multicolumn{3}{|l|}{ Education attainment } \\
\hline No formal education & 6 & 6.67 \\
\hline Primary & 26 & 28.89 \\
\hline Secondary & 39 & 43.33 \\
\hline Tertiary & 19 & 21.11 \\
\hline \multicolumn{3}{|l|}{ Occupation } \\
\hline Full time & 60 & 66.67 \\
\hline Part time & 30 & 33.33 \\
\hline \multicolumn{3}{|l|}{ Farming experience } \\
\hline $6-10$ & 45 & 50.00 \\
\hline $11-15$ & 42 & 46.67 \\
\hline$>15$ & 3 & 3.33 \\
\hline \multicolumn{3}{|l|}{ Loan amount } \\
\hline $30,000-50,000$ & 42 & 46.67 \\
\hline $51,000-70,000$ & 9 & 10.00 \\
\hline $71,000-90,000$ & 15 & 16.67 \\
\hline $91,000-110,000$ & 15 & 16.67 \\
\hline $111,000-130,000$ & 6 & 6.67 \\
\hline$>130,000$ & 3 & 3.33 \\
\hline \multicolumn{3}{|l|}{ Farm size } \\
\hline $0.1-2.0$ & 3 & 3.33 \\
\hline $2.1-4.0$ & 48 & 53.33 \\
\hline$>4.0$ & 39 & 43.33 \\
\hline Total & 90 & 100 \\
\hline
\end{tabular}

Source: field survey, 2014. 
had a household size of between one persons and five persons. The result indicates that the household size is large; this will help the farmers not to spend much money hiring labourers. This result is in agreement with Osondu et al. [14], who stated that in the presence of constraints to farm labour availability, large households tend to use family members as sources of labour. Large households, whose labour is fully employed for agricultural production, would contribute to labour input for increase and sustainable production. In this case, credit obtained could be efficiently utilized. On the other hand, larger household size could lead to loan diversions resulting from increase in consumption expenses. In relation to level of formal education attainment, the table shows that a fair percentage $(43.33 \%)$ of the respondent's attained secondary education, $28.89 \%$ and $21.11 \%$ of them had primary and tertiary education, respectively, while only $6.67 \%$ of them had no formal education. Cumulatively, the table shows that majority $(93.33 \%)$ of the respondents can marginally be classified as literate. It is expected that the majority of these respondents will be articulate enough in their decision making process, managerial skills and high level of awareness of credit facilities, for increased, sustainable and profitable production.

Table 1 further indicates that $66.67 \%$ of the respondents were full time farmers, while $33.33 \%$ were part time farmers. The need to supplement household income made some respondents diversify sources of income. In terms of farming experience, a fairly good number $(50.00 \%)$ had 6-10 years of farming experience, $46.67 \%$ had between 11 years to 15 years, while $3.33 \%$ had more than 15 years of farming experience. This indicates that most of these respondents are well grounded in the rudiments of farming and can make efficient use of credit facilities if extended to them. The table further shows that $56.67 \%$ of the farmers borrowed between 30 thousand Naira $(\$ 30,000.00)$ to 70 thousand Naira only ( $\$ 70,000.00$ ), 33.34\% borrowed between 71 thousand Naira only ( $\$ 71,000.00)$ to 110 thousand Naira only
(\$110,000.00), while 10.0\% borrowed more than 110 thousand Naira only ( $\$ 110,000.00)$. It was also observed that $53.33 \%$ of respondents had between 0.1 ha and 2.0 ha of farmland, $43.33 \%$ had between 2.1 ha and 4.0 ha of farm land, and $3.33 \%$ of the respondents had above 4.0 ha of farmland. The result implies that most of the farmers in the study area had relatively small farm holdings and hence were small scale farmers. This result lends further credence to an assertion by Olawepo [15] that over $90 \%$ of the country's local food production comes from small scale farms and about $60 \%$ of the population earns their living from small farms which are usually of the size of about 0.10-5.99 ha.

\subsection{Sources of Agricultural Credit}

Table 2 shows that the main sources of credit available to the farmers in the study area were co-operative societies $(43.33 \%)$, friends or relatives (30.00\%), money lenders (14.44\%), commercial banks (1.11\%), agricultural banks (2.22\%) and microfinance banks $(8.89 \%)$. The implication is that the major sources of credit among the respondents were personal savings, friends or relatives and co-operative societies, which are non-institutional credit sources. Credit from non-institutional sources is more attractive, because there is little or no insistence on collateral security. On the other hand, formal sources of credit had low patronage from the farmers, which may be due to lack or limited presence of banks in the study area coupled with delay in approval and disbursement of loan and insistence on collateral security.

Table 2 Frequency distribution of respondents according to their sources of credit.

\begin{tabular}{lll}
\hline Source of credit & Frequency & Percentage (\%) \\
\hline Friends or relatives & 27 & 30.00 \\
Cooperative societies & 39 & 43.33 \\
Money lenders & 13 & 14.44 \\
Commercial banks & 1 & 1.11 \\
Agricultural banks & 2 & 2.22 \\
Micro finance banks & 8 & 8.89 \\
Total & 90 & 100.00 \\
\hline Source: field survey, 2014 &
\end{tabular}


Table 3 Regression estimates of the socio-economic determinants of volume of credit obtained.

\begin{tabular}{|c|c|c|c|c|}
\hline Variable & Linear & Exponential $^{+}$ & Double log & Semi-log \\
\hline \multirow[t]{2}{*}{ Constant } & 64.736 & 3.536 & 4.996 & 162.188 \\
\hline & $(2.52)^{* * *}$ & $(10.74) * * *$ & $(8.82)^{* * *}$ & $(3.71)^{* * *}$ \\
\hline \multirow[t]{2}{*}{ Age $\left(x_{1}\right)$} & -0.603 & -0.009 & -0.380 & -25.593 \\
\hline & $(-3.51)^{* * *}$ & $(-3.94)^{* *}$ & $(-4.57)^{* * *}$ & $(-3.01)^{* * *}$ \\
\hline \multirow[t]{2}{*}{ Household size $\left(x_{2}\right)$} & 5.233 & 0.064 & 0.355 & 27.54 \\
\hline & $(4.63)^{* * *}$ & $(3.94)^{* * *}$ & $(3.44)^{* * *}$ & $(3.00)^{* * *}$ \\
\hline \multirow[t]{2}{*}{ Education level $\left(x_{3}\right)$} & 1.115 & 0.020 & 0.224 & 12.579 \\
\hline & $(2.13)^{* *}$ & $(2.97)^{* * *}$ & $(-4.51)^{* *}$ & $(2.19)^{* *}$ \\
\hline \multirow[t]{2}{*}{ Farming experience $\left(x_{4}\right)$} & 1.672 & 0.024 & 0.155 & 10.660 \\
\hline & $(1.50)$ & $(1.37)$ & $(1.61)^{*}$ & $(1.43)$ \\
\hline \multirow[t]{2}{*}{ Farm size $\left(x_{5}\right)$} & 27.488 & 0.466 & 0.867 & 16.193 \\
\hline & $(1.81)^{*}$ & $(2.20)^{* *}$ & $(9.03)^{* * *}$ & $(1.75)^{*}$ \\
\hline \multirow[t]{2}{*}{ Loan repayment $\left(x_{6}\right)$} & 13.708 & 0.191 & 0.228 & 16.193 \\
\hline & $(2.43)^{* *}$ & $(2.65)^{* * *}$ & $(1.17)$ & $(2.75)^{* * *}$ \\
\hline \multirow[t]{2}{*}{ Gender $\left(x_{7}\right)$} & -5.161 & -0.012 & -0.31 & -6.383 \\
\hline & $(-1.32)$ & $(-0.23)$ & $(-0.58)$ & $(4.80)^{* * *}$ \\
\hline \multirow[t]{2}{*}{ Membership to cooperative society $\left(x_{8}\right)$} & 12.500 & 0.689 & 6.166 & 13.641 \\
\hline & $(1.45)$ & $(2.70)^{* * *}$ & $(2.33)^{* *}$ & $(1.80)^{*}$ \\
\hline \multirow[t]{2}{*}{ Marital status $\left(x_{9}\right)$} & 6.282 & 0.789 & 0.114 & 8.493 \\
\hline & $(3.83)^{* * *}$ & $(1.67)^{*}$ & $(4.35)^{* * *}$ & $(4.65)^{* * *}$ \\
\hline \multirow[t]{2}{*}{ Status of farming full $\left(x_{10}\right)$} & -18.550 & -0.166 & -0.263 & -24.512 \\
\hline & $(-3.91)^{* * *}$ & $(-2.24)^{* *}$ & $(-4.35)^{* * *}$ & $(-5.245)^{* * *}$ \\
\hline$R^{2}$ & 0.8849 & 0.9035 & 0.8883 & 0.8696 \\
\hline Adjusted $R^{2}$ & 0.8703 & 0.8913 & 0.8741 & 0.8531 \\
\hline$F$-ratio & $(66.71)^{* * *}$ & $(73.96)^{* * *}$ & $(62.80)^{* * *}$ & $(52.70)^{* * *}$ \\
\hline
\end{tabular}

Source: computation from field survey, 2014. Numbers in parenthesis are the $t$-ratio. $* * *, * *$ and $*$ indicate variables are significant at $1.0 \%, 5.0 \%$ and $10.0 \%$ risk level, respectively. ${ }^{+}$Lead equation.

\subsection{Factors Influencing Amount of Agricultural Credit} Acquired by Farmers

Table 3 shows the regression estimate of determinants of credit obtained by farmers in Idemili North local government area of Anambra State. The exponential functional form was chosen as the lead equation based on the magnitude of $R^{2}$, the significant level of the $F$-ratio, the number of significant variables and the conformity of the variables to a priori expectations. The exponential functional form posted $R^{2}$ value of 0.9035 , which indicates that $90.35 \%$ variation in farmers' acquisition of agricultural credit is accounted for the selected explanatory variables. It suggests that the model has explanatory power on the changes in farmers' acquisition of agricultural credit.

The coefficient of age $(-0.009)$ was negatively signed and significant at $1.0 \%$ level. This result implies that the amount of agricultural credit acquired by farmers decreases with age. The result is in agreement with priori expectation. Older farmers are relatively more risk averse and tend to acquire fewer loans to avoid loan default.

Household size had a positive coefficient (0.064), which was significant at $1.0 \%$ level. This means that the amount of agricultural credit acquired and household size had direct correlation. This result is also in agreement with priori expectation. As the size of a household increases, the household needs will also increase. In a bid to satisfy the increased household needs, relatively larger amount of loans will be acquired. However, the tendency for diversion of agricultural loan to consumption purposes also 
increases with household size.

The coefficient of membership of cooperative societies (0.689) was positive and significant at $\alpha=$ $1.0 \%$. This implies a direct relationship between membership of cooperative societies and amount of agricultural credit acquired. According to Aribaba [16], cooperative societies enable members' to save and mobilize funds for use in sectors where such funds are needed.

The coefficient of marital status (0.789) and occupational status (-0.166) were positive and significant at $10.0 \%$ and $5.0 \%$ levels of probability, respectively. This implies that any increase in their variables would lead to an increase in level of credit obtained. The posture of this result implies that single farmers in the study area acquired less agricultural credit. Married farmers have relatively larger household sizes, which serves as a drive to obtain agricultural credit in the area. Also lenders view married farmers as being relatively more stable, responsible and capable of repaying borrowed funds. In terms of occupational status, full time farmers obtained more agricultural credit than part time farmers. The need to invest more funds on their sole means of livelihood could have accounted for this result.

The coefficient $(0.020)$ of education level was positive and significant at $\alpha=1.0 \%$. This result conforms to priori expectations and implies that amount of agricultural credit acquired increases with education level. Expectedly, educated farmer borrowers have better tendency for loan management and adoption of new productivity enhancing technologies. This positive attribute increases loan repayment potential, which is attractive to lenders.

The coefficient of farm size (0.466) was significantly and positively signed at $5.0 \%$ level. This means that the greater the farm size, the greater the amount of agricultural credit acquired. This is because increase in farm size will lead to increased farm inputs and subsequently increased profit and more quests for loan. This conforms to priori expectations and corroborates that increase in farm size increases amount of acquired loan [17].

The coefficient of amount of loan repaid (0.191) was significantly positive at $\alpha=1.0 \%$. This implies that an increase in this variable is expected to lead to an increase in the volume of agricultural credit borrowed. This is in line with priori expectation. Ability to repay loans qualifies one to obtain more loan. When farmers repay borrowed credit on time without default, lenders will be willing to release more to them. According to Afolabi [18], formal credit sources are not willing to extend loans to small scale farmers, due to their low level of loan repayment. This is an agreement with priori expectation.

\subsection{Misappropriation of Agricultural Credit among the Farmers}

The result in Table 4 shows that a good proportion $(53.33 \%)$ of the farmers did not misappropriate the agricultural credit accessed; 37.78\% misappropriated agricultural credit accessed, while $8.89 \%$ did not indicate whether they misappropriated accessed credit or not. This result implies that the production and repayment potentials of a good proportion (53.33\%) of the farmers in the study area could have been enhanced by the appropriation of agricultural credit

Table 4 Distribution of respondents according to misappropriation of agricultural credit.

\begin{tabular}{lll}
\hline Variable & Frequency & Percentage (\%) \\
\hline Misappropriation of credit & & \\
\hline Misappropriate & 34 & 37.78 \\
Did not misappropriate & 48 & 53.33 \\
No response & 8 & 8.89 \\
Total & 90 & 100 \\
\hline Reason for misappropriation & & \\
\hline Low yield/returns & 11 & 32.35 \\
Meeting household food needs & 3 & 8.82 \\
Meeting household non-food & 19 & 55.89 \\
needs & 1 & 2.94 \\
Defrauded off the money & 34 & 100 \\
Total & & \\
\hline
\end{tabular}

Source: field survey, 2014. 
Table 5 Distribution of respondents according to problems encountered in the quest of credit acquisition.

\begin{tabular}{lll}
\hline Loan & Frequency $^{+}$Percentage $^{+}(\%)$ \\
\hline Lack of collateral & 68 & 75.56 \\
Distance from source of credit & 45 & 50.00 \\
Moratorium & 30 & 33.33 \\
Poor harvest & 34 & 37.78 \\
Delay in approval/disbursement & 40 & 44.44 \\
High interest rate & 71 & 78.89 \\
\hline
\end{tabular}

Source: field survey, 2014. ${ }^{+}$Multiple responses.

obtained for the acquisition of the needed production resources. If these farmers adequately were motivated by granting them access to agricultural credit, it could make meaningful impact on agricultural production.

Table 4 further shows the various reasons why some farmers obtained agricultural credit in the study area channeled the credit to other areas instead of agricultural sector. The table result shows that a good proportion $(55.89 \%)$ of farmers who misappropriated acquired credit used the funds to meet household nonfood needs. These include payment of children school fees, hospital bills, renovation of house and buying cloths and other properties. $32.35 \%$ of these farmers misappropriated the agricultural credit due to low returns or yield. Not surprisingly, few $(8.82 \%)$ of the farmers who misappropriated the acquired credit, did it to meet household food needs. The farmers are small scale producers and tend to consume most of the produce. And most times their expenses on procuring food are relatively lower in comparison to expenses on other household needs.

\subsection{Constraints Limiting Farmers from Acquiring Agricultural Credit}

Table 5 presents the percentage distribution of respondents according to the constraints to acquiring agricultural credit. The table result shows that majority $(78.89 \%)$ and $(75.56 \%)$ of the respondents faced high interest rate and lacked of collateral, respectively, as major problems in their quest for acquiring agricultural credit. This finding agrees with Von-Pischike [19], who noted that creditors generally charged exorbitant rates from farmers and in some cases extracted economic surplus provided by peasant labour, capital and possibly land. Due to the risk of loan default, most formal and some informal sources require collateral as a prerequisite for credit acquisition. The table also shows that $50.00 \%$ and $44.44 \%$ of the respondents were constrained by poor harvest and delay in loan approval or disbursement. Farmers' failure to realize expected harvest and income could lead to loan default, which would prevent them from acquiring more loans. Another dimension to the problem of poor harvest is that the amount saved by farmers in their various informal savings institutions would be seriously affected.

\section{Conclusions and Policy Implication}

The outcome of the study revealed that agricultural activity in the study area were carried out mostly by married males who are educated with large household size and still in their productive years. They are mostly full time farmers with small to medium farm holdings, who sourced agricultural credit mainly from the informal sources. Cumulatively, $87.78 \%$ of the farmers acquired agricultural credit form informal sources, while only $12.22 \%$ of the farmers acquired credit from formal sources.

The result of the multiple regression analysis revealed that age, household size, membership of cooperative societies, marital status, education level, farm size and amount of loan repaid were significant predictors at varied signs and levels of amount of agricultural credit acquired by farmers. The most common reason given among the respondents, who misappropriated acquired agricultural credit, was to meet nonfood needs of the household. The farmers encountered problems of high interest rate, lack of collateral, long distance from source of credit, poor harvest, moratorium and delay in loan approval or disbursement attack in their bid to acquire credit. Education level influenced credit acquisition. In line with the research findings, the state government should pass policies aimed at providing free educative seminars to all illiterate farmers to teach them possible 
ways and methods of acquiring credit. To ensure mass attendance to such seminars, little incentives should be given to farmer participants.

The coefficient for farming experience and farm size was positively related to volume of credit obtained. Policies on land redistribution to make more land available to the farmers, especially the experienced farmers, should be promulgated. This calls for full implementation of the land use act of 1978.

Membership to cooperative societies increased amount of credit acquired by farmers for agricultural production. Hence, the relevant government agencies should mobilize the rural farmers and encourage them to join cooperative associations, so that they can derive maximum benefit of collective investment of group savings, as well as increase their chances of accessing formal agricultural credit facilities because of the comparative advantages associated with cooperative societies.

There should be a deliberate policy to ensure that rural farmers have access to adequate credit facilities. This, no doubt, will go a long way to boost the production capacity of the farmers, thereby increasing their farm income. To achieve it, deliberate policy to ensure peasant farmers acquisition of agricultural credit should be put in place. Long term solutions should be provided by government at all levels to solve the recurrent problem of high interest rate and absence of collateral as farmers' constraints to production credit.

In line with the finding of this study, it is recommended that financial institutions, such as agricultural and micro finance banks, should be established in the rural areas. The procedures for securing loans should also be streamlined in order to make it simple for the farmers.

\section{References}

[1] Central Bank of Kenya (CBK). 1998. Monthly Economic Review.

[2] Amao, J. O., Adebayo, O. O., and Anaynwuyi, E. 2003. "Analysis of Factors Affecting Income Generation among Farmers' Group in Illorin East Local Government Area of Kwara State of Nigeria." International Journal of
Economic and Development 3 (1): 20-8.

[3] Asogwa, B. C., Abu1, O., and Ochoche, G. E. 2014. “Analysis of Peasant Farmers' Access to Agricultural Credit in Benue State, Nigeria." British Journal of Economics, Management and Trade 4 (10): 1525-43.

[4] Alfred, S. D. Y. 2005. "Effect of Extension Information on Credit Utilization in a Democratic and Deregulated Economy by Farmers in Ondo State of Nigeria." J. Agr. Exten. 8: 135-40.

[5] Nnanna, O. J. 2004. "The Role of Central Bank of Nigeria in Enterprise Financing." Central Bank of Nigeria Bullion 27 (1): 19-28.

[6] Olaitan, M. A. 2006. "Finance for Small and Medium Enterprises, Nigeria's Agricultural Credit Guarantee Scheme Fund." Journal of International Farm Management 3 (2): 1-9.

[7] Nwaru, J. C., Onyenweaku, C. E., and Nwosu, A. C. 2006. "Relative Technical Efficiency of Credit and Non-credit User Crop Farmers.” African Crop Science Journal 14 (3): 241-51.

[8] Adebayo, O. O., and Adeola. R. G. 2008. "Sources and Uses of Agricultural Credit by Small Scale Farmers in Surulere Local Government Area of Oyo State." Anthropologist 10 (4): 313-4.

[9] Ijere, M. O., and Mbanasor, J. A. 1998. "Agricultural Credit and Economic Development." In Readings in Agricultural Finance, edited by Ijere, M. O., and Okorie, A. Lagos: Longman Nigeria Plc., 111-5.

[10] Usmans, S. 1999. "Industrial Financing: The Role of Banks.” Nigeria Financial Review 8 (2): 6-12.

[11] Okorie, A. 1998. "Management of Risk and Default in Agricultural Lending." In Reading in Agricultural Finance, edited by Ijere, M. O., and Okorie, A. Lagos: Longman Nigeria Plc., 90-105.

[12] National Population Commission (NPC). 2006. The Population Census of the Federal Republic of Nigeria Analytical Report.

[13] Olaleye, R. 2000. "Effectiveness of Development Intervention for Economic Empowerment on Rural Women in Ondo Nigeria." Ph.D. thesis, Department of Agricultural Extension and Rural Development, University of Ibadan, Ibadan.

[14] Osondu, C. K., Ezeh, C. I., Emerole, C. O., and Anyiro, C. O. 2014. "Comparative Analysis of Technical Efficiency of Small Holder Fadama II and Fadama III Cassava Farmers in Imo State, Nigeria." Nigerian Journal of Rural Extension and Development 8: 26-37.

[15] Olawepo, R. A. 2010. "Determining Rural Farmers' Income: A Rural Nigeria Experience." Journal of African Studies Development 2 (4): 99-108.

[16] Aribaba, F. O. 2013. "An Investigation of the Performance of Cooperative Thrift and Credit Societies in Financing Small-Scale Businesses in Nigeria." 
Farmers in Idemili Local Government Area of Anambra State

Mediterranean Journal of Social Sciences 4 (1): 401-6.

[17] Essein, U. A. 2009. “Gender, Informal Credit Markets and Determinants of Credit Use by Food Crop Farmers in Akwa Ibom State of Nigeria." M.Sc. thesis, Department of Agricultural Economics and Extension, Michael Okpara University of Agriculture, Umudike, Nigeria.

[18] Afolabi, J. A. 2008. "Analysis of Loan Repayment among Small Scale Farmers in South Western Nigeria-A Discriminant Approach." Journal of Social Sciences 17 (1): 83-9.

[19] Von-Pischike, J. D. 1991. A Critical Survey of Approaches to the Role of Credit in Small Holder Development Discussion Paper. Institute for Development Studies, University of Nairobi. 